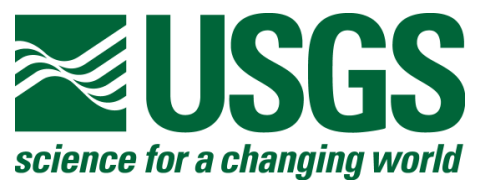

\title{
Four Models used for Numerical Simulation of a Borehole Radar Antenna
}

By Karl J. Ellefsen and David L. Wright

This report is preliminary and has not been reviewed for conformity with U.S. Geological Survey editorial standards or with the North American Stratigraphic Code.

Any use of trade, product, or firm names is for descriptive purposes only and does not imply endorsement by the U.S. Government.

Open-File Report 2003-03-155

U.S. Department of the Interior

U.S. Geological Survey 


\begin{abstract}
In this report are four different models that represent an antenna used by personnel at the U.S. Geological Survey for crosswell investigations. The four models vary in complexity and concomitantly the accuracy with which they represent the actual antenna. These models are used in numerical simulations of the antenna to determine how it radiates radar waves.
\end{abstract}




\section{INTRODUCTION}

The transmitting antenna used at the U.S. Geological Survey was represented by four different models that were used in numerical simulations to calculate its radiation pattern. The complexity of the models and concomitantly the accuracy with which they represent the transmitting antenna varied.

These four models will be useful in future investigations, and so detailed descriptions of the models are in this report. Because the descriptions are straightforward, only a few remarks are necessary:

- The four models are labeled MODEL 1, MODEL 2, MODEL 3, and MODEL 4. The complexity of the models increases with model number. In other words, model 1 is the least complex, and model 4 is the most complex.

- Each model is described in a separate section of the report.

- The parts in the models are labeled with numbers. The same numbers are used for the same (or nearly the same) part in different models, to make their comparison somewhat easy. For example, the fiberglass cover in all models is labeled " 3 ." Because of this method of numbering, the numbering for the parts in models 1,2 , and 3 is not consecutive. For example, model 1 has parts labeled " 1 " and " 3 ," but not " 2 ."

- The dimensions of the models are specified in the circular cylindrical coordinate system, and its origin is at the center of the driving point. The models have cylindrical symmetry, and so locations within the model are completely specified with just the radial and the axial distances ( $\rho$ and $z$, respectively). All dimensions use five digits to the right of the decimal place (for example, 0.00520).

- The electromagnetic properties are specified using three significant digits.

- In all four models, the space occupied by the coaxial cable (regions 27, 28, and 29) overlaps the space occupied by the driving point and the cylindrical conductors (region 10). While this appears to be an error, it is not. One finite difference grid is used for the coaxial cable, and another, larger grid is used for the rest of the antenna. The two grids are joined at the driving point. 


\section{MODEL 1}

(a) Entire Model

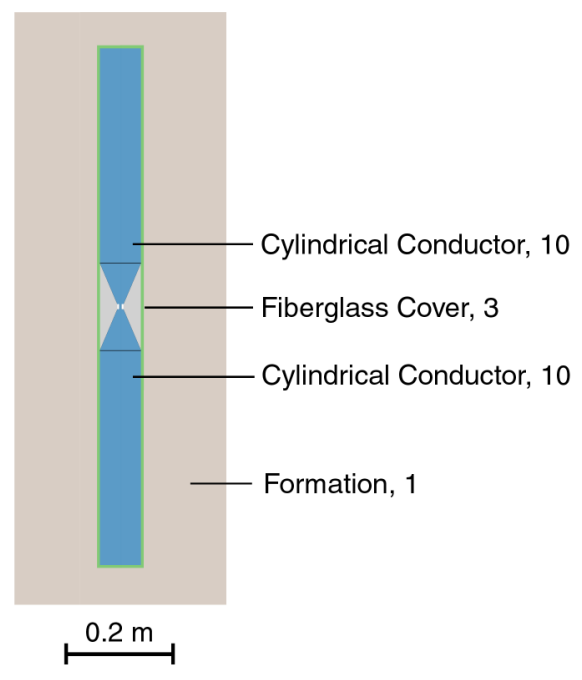

(b) Closeup View of Driving Point

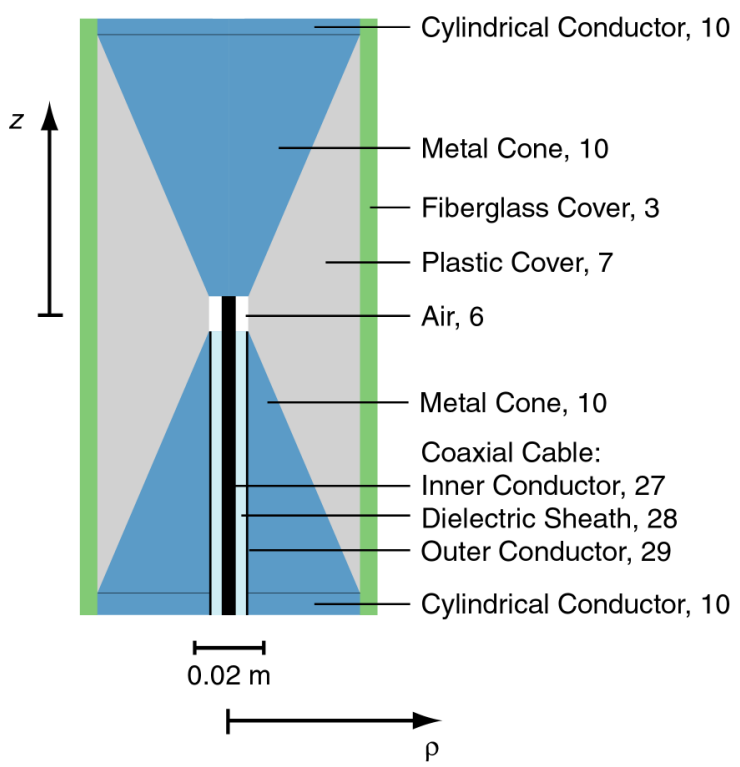

Figure 1. Model 1. Both diagrams are to scale and may be compared to the diagrams in Figures 2, 3, and 4. Each region of the model is referenced by a number. The electromagnetic properties and the dimensions of each region are listed in Tables 1 through 4.

Table 1. Regions of model 1, except for the coaxial cable (Figure 1). Type "s" refers to a region with standard or typical electromagnetic properties. Type "pc" refers to a region that is a perfect conductor. For such a region, both the relative dielectric permittivity and the relative magnetic permeability have no significance; consequently, the associated table entries are leaders (---). The dimensions of the regions are listed in Table 2.

\begin{tabular}{|r|l|r|r|r|r|}
\hline $\begin{array}{r}\text { Region } \\
\text { Number }\end{array}$ & Description & Type & $\begin{array}{r}\text { Electrical } \\
\text { Conductivity } \\
(\mathrm{S} / \mathrm{m})\end{array}$ & $\begin{array}{r}\text { Relative } \\
\text { Dielectric } \\
\text { Permittivity }\end{array}$ & $\begin{array}{r}\text { Relative } \\
\text { Magnetic } \\
\text { Permeability }\end{array}$ \\
\hline 1 & Formation & $\mathrm{s}$ & 0.00 & 5.80 & 1.00 \\
\hline 3 & Fiberglass cover of the sonde & $\mathrm{s}$ & 0.00 & 4.70 & 1.00 \\
\hline 6 & Air near the driving point & $\mathrm{s}$ & 0.00 & 1.00 & 1.00 \\
\hline 7 & Plastic cover of the driving point & $\mathrm{s}$ & 0.00 & 3.70 & 1.00 \\
\hline 10 & Driving point and the cylindrical conductors & $\mathrm{pc}$ & $\infty$ & --- & --- \\
\hline
\end{tabular}


Table 2. Dimensions of regions 1, 3, 6, 7, and 10 in model 1 (Figure 1). Each region has a different shape, and so the number of coordinates needed to describe that shape generally varies.

\begin{tabular}{|r|r|r|r|r|r|r|r|r|r|}
\hline \multicolumn{2}{|c|}{ Region 1 } & \multicolumn{2}{c|}{ Region 3 } & \multicolumn{2}{c|}{ Region 6 } & \multicolumn{2}{c|}{ Region 7 } & \multicolumn{2}{c|}{ Region 10 } \\
\hline$\rho(\mathrm{m})$ & $z(\mathrm{~m})$ & $\rho(\mathrm{m})$ & $z(\mathrm{~m})$ & $\rho(\mathrm{m})$ & $z(\mathrm{~m})$ & $\rho(\mathrm{m})$ & $z(\mathrm{~m})$ & $\rho(\mathrm{m})$ & $z(\mathrm{~m})$ \\
\hline 0.00000 & -30.00000 & 0.0000 & -0.48490 & 0.00200 & -0.00510 & 0.03810 & 0.08100 & 0.00000 & -0.47980 \\
\hline 0.00000 & -0.48490 & 0.00000 & -0.47980 & 0.00570 & -0.00510 & 0.00570 & 0.00510 & 0.03810 & -0.47980 \\
\hline 0.04320 & -0.48490 & 0.03810 & -0.47980 & 0.00570 & 0.00510 & 0.00570 & -0.00510 & 0.03810 & -0.08100 \\
\hline 0.04320 & 0.48490 & 0.03810 & 0.47980 & 0.00200 & 0.00510 & 0.03810 & -0.08100 & 0.00570 & -0.00510 \\
\hline 0.00000 & 0.48490 & 0.00000 & 0.47980 & & & & & 0.00200 & -0.00510 \\
\hline 0.00000 & 30.00000 & 0.00000 & 0.48490 & & & & & 0.00200 & 0.00510 \\
\hline 30.00000 & 30.00000 & 0.04320 & 0.48490 & & & & & 0.00570 & 0.00510 \\
\hline 30.00000 & -30.00000 & 0.04320 & -0.48490 & & & & & 0.03810 & 0.08100 \\
\hline & & & & & & & & 0.03810 & 0.47980 \\
\hline & & & & & & & & 0.00000 & 0.47980 \\
\hline
\end{tabular}

Table 3. Coaxial cable used in model 1 (Figure 1). Type "s" refers to a region with standard or typical electromagnetic properties. Type "pc" refers to a region that is a perfect conductor. For such a region, both the relative dielectric permittivity and the relative magnetic permeability have no significance; consequently, the associated table entries are leaders (---). The dimensions are listed in Table 4.

\begin{tabular}{|r|l|r|r|r|r|}
\hline $\begin{array}{r}\text { Region } \\
\text { Number }\end{array}$ & Description & Type & $\begin{array}{r}\text { Electrical } \\
\text { Conductivity } \\
(\mathrm{S} / \mathrm{m})\end{array}$ & $\begin{array}{r}\text { Relative } \\
\text { Dielectric } \\
\text { Permittivity }\end{array}$ & $\begin{array}{r}\text { Relative } \\
\text { Magnetic } \\
\text { Permeability }\end{array}$ \\
\hline 27 & Inner Conductor & $\mathrm{pc}$ & $\infty$ & --- & --- \\
\hline 28 & Dielectric Sheath & $\mathrm{s}$ & 0.00 & 1.30 & 1.00 \\
\hline 29 & Outer Conductor & $\mathrm{pc}$ & $\infty$ & --- & --- \\
\hline
\end{tabular}

Table 4. Dimensions of the coaxial cable used for model 1 (Figure 1).

\begin{tabular}{|r|r|r|r|r|r|}
\hline \multicolumn{2}{|c|}{ Region 27} & \multicolumn{2}{c|}{ Region 28} & \multicolumn{2}{c|}{ Region 29} \\
\hline$\rho(\mathrm{m})$ & $z(\mathrm{~m})$ & $\rho(\mathrm{m})$ & $z(\mathrm{~m})$ & $\rho(\mathrm{m})$ & $z(\mathrm{~m})$ \\
\hline 0.00000 & -0.02910 & 0.00200 & -0.02910 & 0.00520 & -0.02910 \\
\hline 0.00000 & -0.00510 & 0.00200 & -0.00510 & 0.00520 & -0.00510 \\
\hline 0.00200 & -0.00510 & 0.00520 & -0.00510 & 0.00550 & -0.00510 \\
\hline 0.00200 & -0.02910 & 0.00520 & -0.02910 & 0.00550 & -0.02910 \\
\hline
\end{tabular}




\section{MODEL 2}

(a) Entire Model

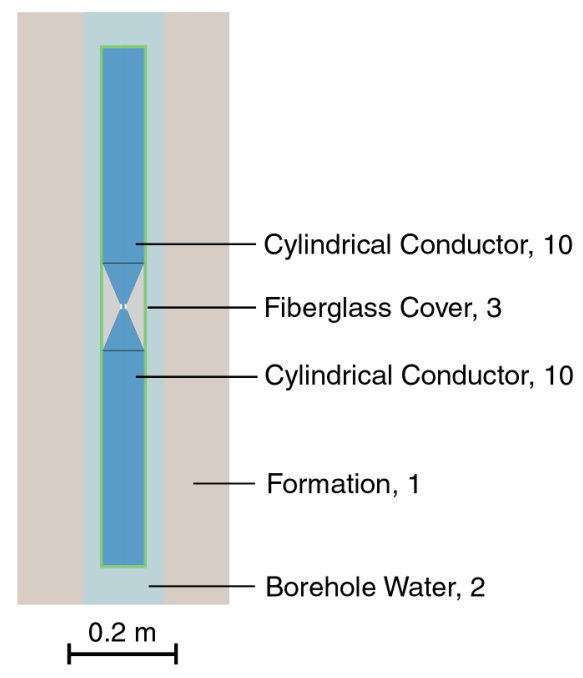

(b) Closeup View of Driving Point

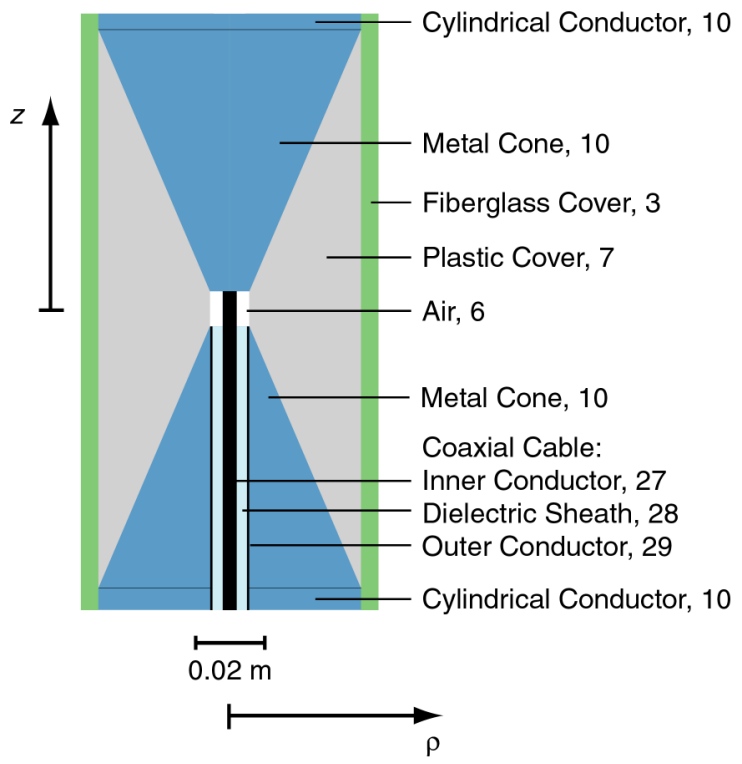

Figure 2. Model 2. Both diagrams are to scale and may be compared to the diagrams in Figures 1, 3, and 4. Each region of the model is referenced by a number. The electromagnetic properties and the dimensions of each region are listed in Tables 5 through 9.

Table 5. Regions of model 2, except for the coaxial cable (Figure 2). Type "s" refers to a region with standard or typical electromagnetic properties. Type "pc" refers to a region that is a perfect conductor. For such a region, both the relative dielectric permittivity and the relative magnetic permeability have no significance; consequently, the associated table entries are leaders (---). The dimensions of the regions are listed in Tables 6 and 7.

\begin{tabular}{|r|l|r|r|r|r|}
\hline $\begin{array}{r}\text { Region } \\
\text { Number }\end{array}$ & Description & Type & $\begin{array}{r}\text { Electrical } \\
\text { Conductivity } \\
(\mathrm{S} / \mathrm{m})\end{array}$ & $\begin{array}{r}\text { Relative } \\
\text { Dielectric } \\
\text { Permittivity }\end{array}$ & $\begin{array}{r}\text { Relative } \\
\text { Magnetic } \\
\text { Permeability }\end{array}$ \\
\hline 1 & Formation & $\mathrm{s}$ & 0.00 & 5.80 & 1.00 \\
\hline 2 & Water in borehole & $\mathrm{s}$ & 0.00 & 81.00 & 1.00 \\
\hline 3 & Fiberglass cover of the sonde & $\mathrm{s}$ & 0.00 & 4.70 & 1.00 \\
\hline 6 & Air near the driving point & $\mathrm{s}$ & 0.00 & 1.00 & 1.00 \\
\hline 7 & Plastic cover of the driving point & $\mathrm{s}$ & 0.00 & 3.70 & 1.00 \\
\hline 10 & Driving point and the cylindrical conductors & $\mathrm{pc}$ & $\infty$ & --- & -- \\
\hline
\end{tabular}


Table 6. Dimensions of regions 1, 2, 3, 6, and 7 in model 2 (Figure 2). Each region has a different shape, and so the number of coordinates needed to describe that shape generally varies.

\begin{tabular}{|r|r|r|r|r|r|r|r|r|r|}
\hline \multicolumn{2}{|c|}{ Region 1 } & \multicolumn{2}{c|}{ Region 2 } & \multicolumn{2}{c|}{ Region 3 } & \multicolumn{2}{c|}{ Region 6 } & \multicolumn{2}{c|}{ Region 7 } \\
\hline$\rho(\mathrm{m})$ & $z(\mathrm{~m})$ & $\rho(\mathrm{m})$ & $z(\mathrm{~m})$ & $\rho(\mathrm{m})$ & $z(\mathrm{~m})$ & $\rho(\mathrm{m})$ & $z(\mathrm{~m})$ & $\rho(\mathrm{m})$ & $z(\mathrm{~m})$ \\
\hline 0.07500 & -30.00000 & 0.07500 & -30.00000 & 0.00000 & -0.48490 & 0.00200 & -0.00510 & 0.03810 & 0.08100 \\
\hline 0.07500 & 30.00000 & 0.07500 & 30.00000 & 0.00000 & -0.47980 & 0.00570 & -0.00510 & 0.00570 & 0.00510 \\
\hline 30.00000 & 30.00000 & 0.00000 & 30.0000 & 0.03810 & -0.47980 & 0.00570 & 0.00510 & 0.00570 & -0.00510 \\
\hline 30.00000 & -30.00000 & 0.00000 & 0.48490 & 0.03810 & 0.47980 & 0.00200 & 0.00510 & 0.03810 & -0.08100 \\
\hline & & 0.04320 & 0.48490 & 0.00000 & 0.47980 & & & & \\
\hline & & 0.04320 & -0.48490 & 0.00000 & 0.48490 & & & & \\
\hline & & 0.00000 & -0.48490 & 0.04320 & 0.48490 & & & & \\
\hline
\end{tabular}

Table 7. Dimensions of region 10 in model 2 (Figure 2).

\begin{tabular}{|r|r|}
\hline \multicolumn{2}{|c|}{ Region 10} \\
\hline$\rho(\mathrm{m})$ & $z(\mathrm{~m})$ \\
\hline 0.00000 & -0.47980 \\
\hline 0.03810 & -0.47980 \\
\hline 0.03810 & -0.08100 \\
\hline 0.00570 & -0.00510 \\
\hline 0.00200 & -0.00510 \\
\hline 0.00200 & 0.00510 \\
\hline 0.00570 & 0.00510 \\
\hline 0.03810 & 0.08100 \\
\hline 0.03810 & 0.47980 \\
\hline 0.00000 & 0.47980 \\
\hline
\end{tabular}

Table 8. Coaxial cable used in model 2 (Figure 2). Type "s" refers to a region with standard or typical electromagnetic properties. Type "pc" refers to a region that is a perfect conductor. For such a region, both the relative dielectric permittivity and the relative magnetic permeability have no significance; consequently, the associated table entries are leaders (---). The dimensions are listed in Table 9.

\begin{tabular}{|r|l|r|r|r|r|}
\hline $\begin{array}{r}\text { Region } \\
\text { Number }\end{array}$ & Description & Type & $\begin{array}{r}\text { Electrical } \\
\text { Conductivity } \\
(\mathrm{S} / \mathrm{m})\end{array}$ & $\begin{array}{r}\text { Relative } \\
\text { Dielectric } \\
\text { Permittivity }\end{array}$ & $\begin{array}{r}\text { Relative } \\
\text { Magnetic } \\
\text { Permeability }\end{array}$ \\
\hline 27 & Inner Conductor & $\mathrm{pc}$ & $\infty$ & --- & --- \\
\hline 28 & Dielectric Sheath & $\mathrm{s}$ & 0.00 & 1.30 & 1.00 \\
\hline 29 & Outer Conductor & $\mathrm{pc}$ & $\infty$ & --- & --- \\
\hline
\end{tabular}

Table 9. Dimensions of the coaxial cable used for model 2 (Figure 2).

\begin{tabular}{|r|r|r|r|r|r|}
\hline \multicolumn{2}{|c|}{ Region 27 } & \multicolumn{2}{c|}{ Region 28 } & \multicolumn{2}{c|}{ Region 29 } \\
\hline$\rho(\mathrm{m})$ & $z(\mathrm{~m})$ & $\rho(\mathrm{m})$ & $z(\mathrm{~m})$ & $\rho(\mathrm{m})$ & $z(\mathrm{~m})$ \\
\hline 0.00000 & -0.02910 & 0.00200 & -0.02910 & 0.00520 & -0.02910 \\
\hline 0.00000 & -0.00510 & 0.00200 & -0.00510 & 0.00520 & -0.00510 \\
\hline 0.00200 & -0.00510 & 0.00520 & -0.00510 & 0.00550 & -0.00510 \\
\hline 0.00200 & -0.02910 & 0.00520 & -0.02910 & 0.00550 & -0.02910 \\
\hline
\end{tabular}




\section{MODEL 3}

(a) Entire Model

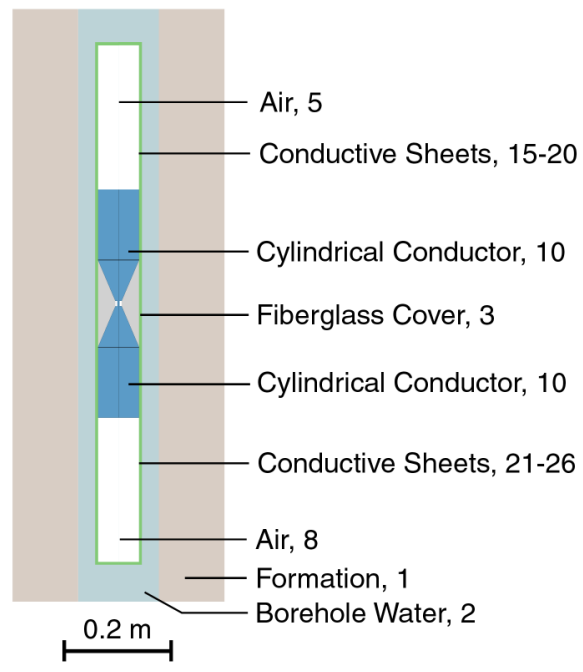

(b) Closeup View of Driving Point

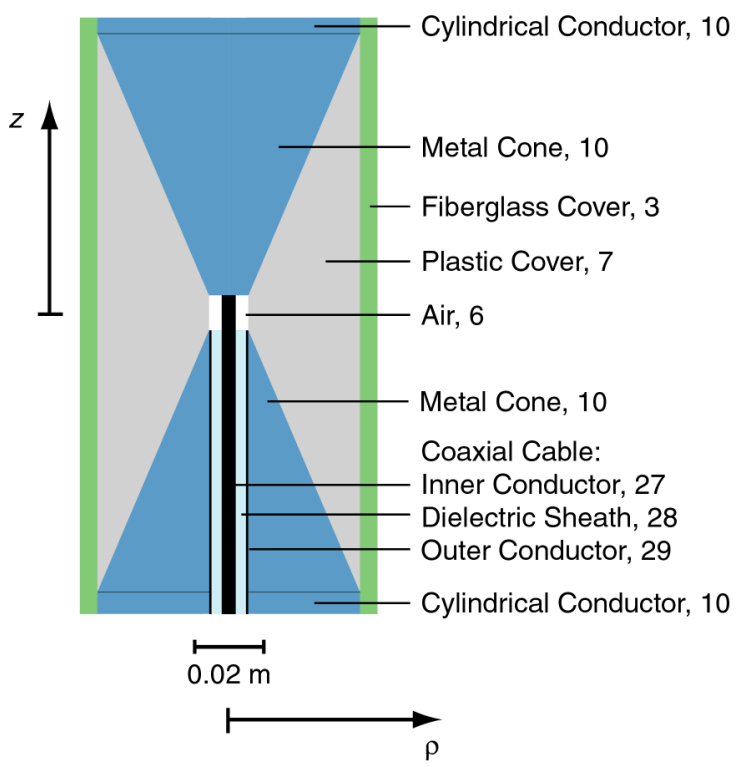

Figure 3. Model 3. Both diagrams are to scale and may be compared to the diagrams in Figures 1, 2, and 4. Each region of the model is referenced by a number. The electromagnetic properties and the dimensions of each region are listed in Tables 10 through 16. 
Table 10. Regions of model 3, except for the coaxial cable (Figure 3). Type "s" refers to a region with standard or typical electromagnetic properties. Type "pc" refers to a region that is a perfect conductor. For such a region, both the relative dielectric permittivity and the relative magnetic permeability have no significance; consequently, the associated table entries are leaders (---). Type "cs" refers to a conductive sheet that is used to simulate the resistive loading on the antenna. The dimensions of the regions are listed in Tables 11 through 14.

\begin{tabular}{|r|l|r|r|r|r|}
\hline $\begin{array}{r}\text { Region } \\
\text { Number }\end{array}$ & Description & Type & $\begin{array}{r}\text { Electrical } \\
\text { Conductivity } \\
(\mathrm{S} / \mathrm{m})\end{array}$ & $\begin{array}{r}\text { Relative } \\
\text { Dielectric } \\
\text { Permittivity }\end{array}$ & $\begin{array}{r}\text { Relative } \\
\text { Magnetic } \\
\text { Permeability }\end{array}$ \\
\hline 1 & Formation & $\mathrm{s}$ & 0.00 & 5.80 & 1.00 \\
\hline 2 & Water in borehole & $\mathrm{s}$ & 0.00 & 81.00 & 1.00 \\
\hline 3 & Fiberglass cover of the sonde & $\mathrm{s}$ & 0.00 & 4.70 & 1.00 \\
\hline 5 & Air behind the upper conductive sheets & $\mathrm{s}$ & 0.00 & 1.00 & 1.00 \\
\hline 6 & Air near the driving point & $\mathrm{s}$ & 0.00 & 1.00 & 1.00 \\
\hline 7 & Plastic cover of the driving point & $\mathrm{s}$ & 0.00 & 3.70 & 1.00 \\
\hline 8 & Air behind the lower conductive sheets & $\mathrm{s}$ & 0.00 & 1.00 & 1.00 \\
\hline 10 & Driving point and the cylindrical conductors & $\mathrm{pc}$ & $\infty$ & --- & --- \\
\hline 15 & $1^{\text {st }}$ conductive sheet, upper Region of antenna & $\mathrm{cs}$ & 75.16 & 4.70 & 1.00 \\
\hline 16 & $2^{\text {nd }}$ conductive sheet, upper Region of antenna & $\mathrm{cs}$ & 64.43 & 4.70 & 1.00 \\
\hline 17 & $3^{\text {rd }}$ conductive sheet, upper Region of antenna & $\mathrm{cs}$ & 52.44 & 4.70 & 1.00 \\
\hline 18 & $4^{\text {th }}$ conductive sheet, upper Region of antenna & $\mathrm{cs}$ & 41.00 & 4.70 & 1.00 \\
\hline 19 & $5^{\text {th }}$ conductive sheet, upper Region of antenna & $\mathrm{cs}$ & 25.05 & 4.70 & 1.00 \\
\hline 20 & $6^{\text {th }}$ conductive sheet, upper Region of antenna & $\mathrm{cs}$ & 14.09 & 4.70 & 1.00 \\
\hline 21 & $1^{\text {st }}$ conductive sheet, lower Region of antenna & $\mathrm{cs}$ & 75.16 & 4.70 & 1.00 \\
\hline 22 & $2^{\text {nd }}$ conductive sheet, lower Region of antenna & $\mathrm{cs}$ & 64.43 & 4.70 & 1.00 \\
\hline 23 & $3^{\text {rd }}$ conductive sheet, lower Region of antenna & $\mathrm{cs}$ & 52.44 & 4.70 & 1.00 \\
\hline 24 & $4^{\text {th }}$ conductive sheet, lower Region of antenna & $\mathrm{cs}$ & 41.00 & 4.70 & 1.00 \\
\hline 25 & $5^{\text {th }}$ conductive sheet, lower Region of antenna & $\mathrm{cs}$ & 25.05 & 4.70 & 1.00 \\
\hline 26 & $6^{\text {th }}$ conductive sheet, lower Region of antenna & $\mathrm{cs}$ & 14.09 & 4.70 & 1.00 \\
\hline
\end{tabular}

Table 11. Dimensions of regions 1, 2, 3, 5, and 6 in model 3 (Figure 3). Each region has a different shape, and so the number of coordinates needed to describe that shape generally varies.

\begin{tabular}{|r|r|r|r|r|r|r|r|r|r|}
\hline \multicolumn{2}{|c|}{ Region 1 } & \multicolumn{2}{c|}{ Region 2 } & \multicolumn{2}{c|}{ Region 3 } & \multicolumn{2}{c|}{ Region 5 } & \multicolumn{2}{c|}{ Region 6 } \\
\hline$\rho(\mathrm{m})$ & $z(\mathrm{~m})$ & $\rho(\mathrm{m})$ & $z(\mathrm{~m})$ & $\rho(\mathrm{m})$ & $z(\mathrm{~m})$ & $\rho(\mathrm{m})$ & $z(\mathrm{~m})$ & $\rho(\mathrm{m})$ & $z(\mathrm{~m})$ \\
\hline 0.07500 & -30.00000 & 0.07500 & -30.00000 & 0.00000 & -0.48490 & 0.00000 & 0.21180 & 0.00200 & -0.00510 \\
\hline 0.07500 & 30.00000 & 0.07500 & 30.00000 & 0.00000 & -0.47980 & 0.03802 & 0.21180 & 0.00570 & -0.00510 \\
\hline 30.00000 & 30.00000 & 0.00000 & 30.00000 & 0.03810 & -0.47980 & 0.03802 & 0.47980 & 0.00570 & 0.00510 \\
\hline 30.00000 & -30.00000 & 0.00000 & 0.48490 & 0.03810 & 0.47980 & 0.00000 & 0.47980 & 0.00200 & 0.00510 \\
\hline & & 0.04320 & 0.48490 & 0.00000 & 0.47980 & & & & \\
\hline & & 0.04320 & -0.48490 & 0.00000 & 0.48490 & & & & \\
\hline & & 0.00000 & -0.48490 & 0.04320 & 0.48490 & & & & \\
\hline
\end{tabular}


Table 12. Dimensions of regions 7, 8, 10, 15, and 16 in model 3 (Figure 3). Each region has a different shape, and so the number of coordinates needed to describe that shape generally varies.

\begin{tabular}{|r|r|r|r|r|r|r|r|r|r|}
\hline \multicolumn{2}{|c|}{ Region 7 } & \multicolumn{2}{c|}{ Region 8 } & \multicolumn{2}{c|}{ Region 10 } & \multicolumn{2}{c|}{ Region 15 } & \multicolumn{2}{c|}{ Region 16 } \\
\hline$\rho(\mathrm{m})$ & $z(\mathrm{~m})$ & $\rho(\mathrm{m})$ & $z(\mathrm{~m})$ & $\rho(\mathrm{m})$ & $z(\mathrm{~m})$ & $\rho(\mathrm{m})$ & $z(\mathrm{~m})$ & $\rho(\mathrm{m})$ & $z(\mathrm{~m})$ \\
\hline 0.03810 & 0.08100 & 0.00000 & -0.21180 & 0.00000 & -0.21180 & 0.03802 & 0.21180 & 0.03802 & 0.25500 \\
\hline 0.00570 & 0.00510 & 0.03802 & -0.21180 & 0.03810 & -0.21180 & 0.03802 & 0.25500 & 0.03802 & 0.29820 \\
\hline 0.00570 & -0.00510 & 0.03802 & -0.47980 & 0.03810 & -0.08100 & 0.03810 & 0.25500 & 0.03810 & 0.29820 \\
\hline 0.03810 & -0.08100 & 0.00000 & -0.47980 & 0.00570 & -0.00510 & 0.03810 & 0.21180 & 0.03810 & 0.25500 \\
\hline & & & & 0.00200 & -0.00510 & & & & \\
\hline & & & & 0.00200 & 0.00510 & & & & \\
\hline & & & & 0.00570 & 0.00510 & & & & \\
\hline & & & & 0.03810 & 0.08100 & & & & \\
\hline
\end{tabular}

Table 13. Dimensions of regions 17 to 21 in model 3 (Figure 3).

\begin{tabular}{|r|r|r|r|r|r|r|r|r|r|}
\hline \multicolumn{2}{|c|}{ Region 17 } & \multicolumn{2}{c|}{ Region 18 } & \multicolumn{2}{c|}{ Region 19 } & \multicolumn{2}{c|}{ Region 20 } & \multicolumn{2}{c|}{ Region 21 } \\
\hline$\rho(\mathrm{m})$ & $z(\mathrm{~m})$ & $\rho(\mathrm{m})$ & $z(\mathrm{~m})$ & $\rho(\mathrm{m})$ & $z(\mathrm{~m})$ & $\rho(\mathrm{m})$ & $z(\mathrm{~m})$ & $\rho(\mathrm{m})$ & $z(\mathrm{~m})$ \\
\hline 0.03802 & 0.29820 & 0.03802 & 0.34140 & 0.03802 & 0.38460 & 0.03802 & 0.42770 & 0.03802 & -0.21180 \\
\hline 0.03802 & 0.34140 & 0.03802 & 0.38460 & 0.03802 & 0.42770 & 0.03802 & 0.47980 & 0.03802 & -0.25500 \\
\hline 0.03810 & 0.34140 & 0.03810 & 0.38460 & 0.03810 & 0.42770 & 0.03810 & 0.47980 & 0.03810 & -0.25500 \\
\hline 0.03810 & 0.29820 & 0.03810 & 0.34140 & 0.03810 & 0.38460 & 0.03810 & 0.42770 & 0.03810 & -0.21180 \\
\hline
\end{tabular}

Table 14. Dimensions of regions 22 to 26 in model 3 (Figure 3).

\begin{tabular}{|r|r|r|r|r|r|r|r|r|r|}
\hline \multicolumn{2}{|c|}{ Region 22 } & \multicolumn{2}{c|}{ Region 23 } & \multicolumn{2}{c|}{ Region 24 } & \multicolumn{2}{c|}{ Region 25 } & \multicolumn{2}{c|}{ Region 26 } \\
\hline$\rho(\mathrm{m})$ & $z(\mathrm{~m})$ & $\rho(\mathrm{m})$ & $z(\mathrm{~m})$ & $\rho(\mathrm{m})$ & $z(\mathrm{~m})$ & $\rho(\mathrm{m})$ & $z(\mathrm{~m})$ & $\rho(\mathrm{m})$ & $z(\mathrm{~m})$ \\
\hline 0.03802 & -0.25500 & 0.03802 & -0.29820 & 0.03802 & -0.34140 & 0.03802 & -0.38460 & 0.03802 & -0.42770 \\
\hline 0.03802 & -0.29820 & 0.03802 & -0.34140 & 0.03802 & -0.38460 & 0.03802 & -0.42770 & 0.03802 & -0.47980 \\
\hline 0.03810 & -0.29820 & 0.03810 & -0.34140 & 0.03810 & -0.38460 & 0.03810 & -0.42770 & 0.03810 & -0.47980 \\
\hline 0.03810 & -0.25500 & 0.03810 & -0.29820 & 0.03810 & -0.34140 & 0.03810 & -0.38460 & 0.03810 & -0.42770 \\
\hline
\end{tabular}

Table 15. Coaxial cable used in model 3 (Figure 3). Type "s" refers to a region with standard or typical electromagnetic properties. Type "pc" refers to a region that is a perfect conductor. For such a region, both the relative dielectric permittivity and the relative magnetic permeability have no significance; consequently, the associated table entries are leaders (---). The dimensions are listed in Table 16.

\begin{tabular}{|r|l|r|r|r|r|}
\hline $\begin{array}{r}\text { Region } \\
\text { Number }\end{array}$ & Description & Type & $\begin{array}{r}\text { Electrical } \\
\text { Conductivity } \\
(\mathrm{S} / \mathrm{m})\end{array}$ & $\begin{array}{r}\text { Relative } \\
\text { Dielectric } \\
\text { Permittivity }\end{array}$ & $\begin{array}{r}\text { Relative } \\
\text { Magnetic } \\
\text { Permeability }\end{array}$ \\
\hline 27 & Inner Conductor & $\mathrm{pc}$ & $\infty$ & --- & --- \\
\hline 28 & Dielectric Sheath & $\mathrm{s}$ & 0.00 & 1.30 & 1.00 \\
\hline 29 & Outer Conductor & $\mathrm{pc}$ & $\infty$ & --- & --- \\
\hline
\end{tabular}


Table 16. Dimensions of the coaxial cable used for model 3 (Figure 3).

\begin{tabular}{|r|r|r|r|r|r|}
\hline \multicolumn{2}{|c|}{ Region 27} & \multicolumn{2}{c|}{ Region 28} & \multicolumn{2}{c|}{ Region 29} \\
\hline$\rho(\mathrm{m})$ & $z(\mathrm{~m})$ & $\rho(\mathrm{m})$ & $z(\mathrm{~m})$ & $\rho(\mathrm{m})$ & $z(\mathrm{~m})$ \\
\hline 0.00000 & -0.02910 & 0.00200 & -0.02910 & 0.00520 & -0.02910 \\
\hline 0.00000 & -0.00510 & 0.00200 & -0.00510 & 0.00520 & -0.00510 \\
\hline 0.00200 & -0.00510 & 0.00520 & -0.00510 & 0.00550 & -0.00510 \\
\hline 0.00200 & -0.02910 & 0.00520 & -0.02910 & 0.00550 & -0.02910 \\
\hline
\end{tabular}




\section{MODEL 4}

\section{(a) Entire Model}

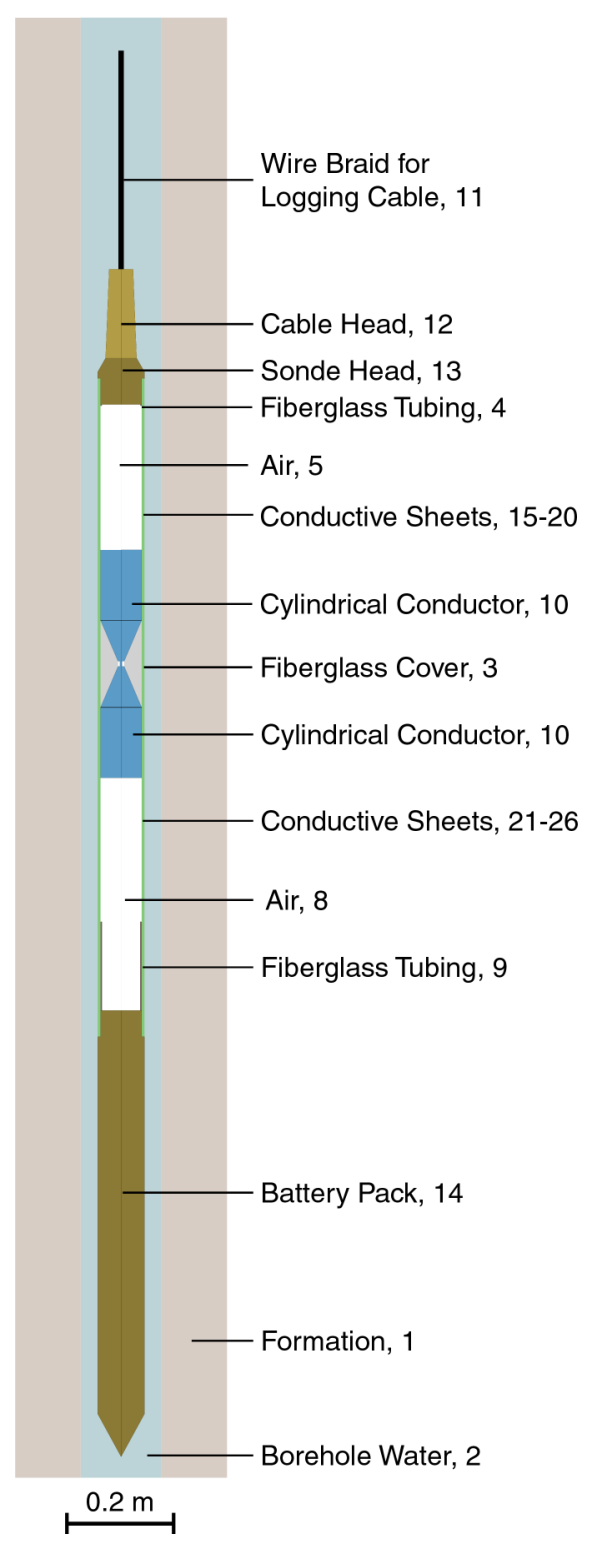

(b) Closeup View of Driving Point

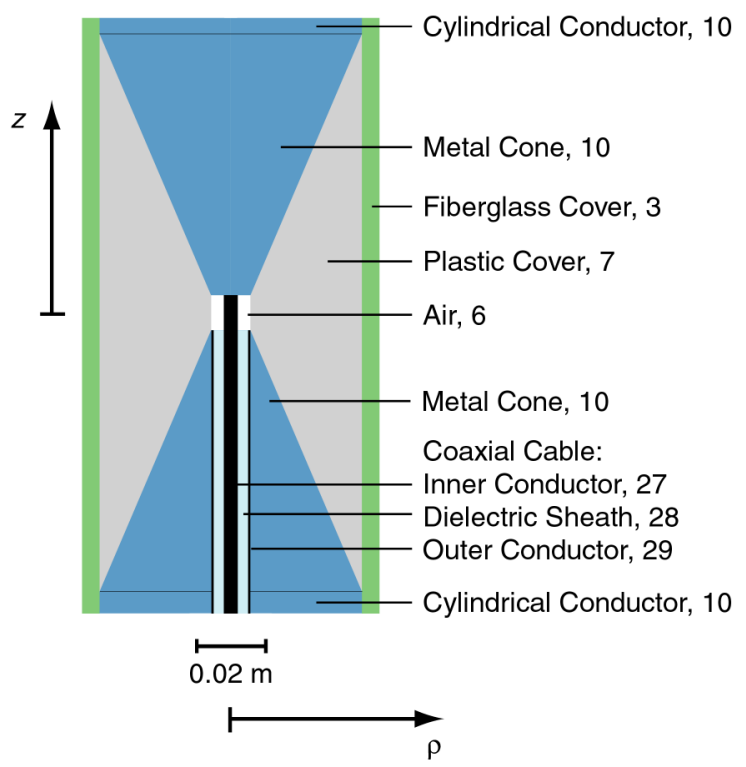

Figure 4. Model 4. Both diagrams are to scale and may be compared to the diagrams in Figures 1, 2, and 3. Each region of the model is referenced by a number. The electromagnetic properties and the dimensions of each region are listed in Tables 17 through 25. 
Table 17. Regions of model 4, except for the coaxial cable (Figure 4). Type "s" refers to a region with standard or typical electromagnetic properties. Type "pc" refers to a region that is a perfect conductor. For such a region, both the relative dielectric permittivity and the relative magnetic permeability have no significance; consequently, the associated table entries are leaders (---). Type "cs" refers to a conductive sheet that is used to simulate the resistive loading on the antenna. The dimensions of the regions are listed in Tables 18 through to 23 .

\begin{tabular}{|c|c|c|c|c|c|}
\hline $\begin{array}{l}\text { Region } \\
\text { Number }\end{array}$ & Description & Type & $\begin{array}{r}\text { Electrical } \\
\text { Conductivity } \\
(\mathrm{S} / \mathrm{m})\end{array}$ & $\begin{array}{r}\text { Relative } \\
\text { Dielectric } \\
\text { Permittivity }\end{array}$ & $\begin{array}{r}\text { Relative } \\
\text { Magnetic } \\
\text { Permeability }\end{array}$ \\
\hline 1 & Formation & $\mathrm{s}$ & 0.00 & 5.80 & 1.00 \\
\hline 2 & Water in borehole & $\mathrm{s}$ & 0.00 & 81.00 & 1.00 \\
\hline 3 & Fiberglass cover of the sonde & $\mathrm{s}$ & 0.00 & 4.70 & 1.00 \\
\hline 4 & Fiberglass tubing near the sonde head & $\mathrm{s}$ & 0.00 & 4.70 & 1.00 \\
\hline 5 & Air behind the upper conductive sheets & $\mathrm{s}$ & 0.00 & 1.00 & 1.00 \\
\hline 6 & Air near the driving point & $\mathrm{s}$ & 0.00 & 1.00 & 1.00 \\
\hline 7 & Plastic cover of the driving point & $\mathrm{s}$ & 0.00 & 3.70 & 1.00 \\
\hline 8 & Air behind the lower conductive sheets & $\mathrm{s}$ & 0.00 & 1.00 & 1.00 \\
\hline 9 & Fiberglass tubing near the battery pack & $\mathrm{s}$ & 0.00 & 4.70 & 1.00 \\
\hline 10 & Driving point and the cylindrical conductors & $\mathrm{pc}$ & $\infty$ & -- & --- \\
\hline 11 & Wire braid for logging cable & pc & $\infty$ & --- & --- \\
\hline 12 & Cable head & $\mathrm{pc}$ & $\infty$ & --- & --- \\
\hline 13 & Sonde head & pc & $\infty$ & --- & --- \\
\hline 14 & Battery pack & pc & $\infty$ & -- & --- \\
\hline 15 & $1^{\text {st }}$ conductive sheet, upper Region of antenna & cs & 75.16 & 4.70 & 1.00 \\
\hline 16 & $2^{\text {nd }}$ conductive sheet, upper Region of antenna & cs & 64.43 & 4.70 & 1.00 \\
\hline 17 & $3^{\text {rd }}$ conductive sheet, upper Region of antenna & cs & 52.44 & 4.70 & 1.00 \\
\hline 18 & $4^{\text {th }}$ conductive sheet, upper Region of antenna & cs & 41.00 & 4.70 & 1.00 \\
\hline 19 & $5^{\text {th }}$ conductive sheet, upper Region of antenna & cs & 25.05 & 4.70 & 1.00 \\
\hline 20 & $6^{\text {th }}$ conductive sheet, upper Region of antenna & cs & 14.09 & 4.70 & 1.00 \\
\hline 21 & $1^{\text {st }}$ conductive sheet, lower Region of antenna & cs & 75.16 & 4.70 & 1.00 \\
\hline 22 & $2^{\text {nd }}$ conductive sheet, lower Region of antenna & cs & 64.43 & 4.70 & 1.00 \\
\hline 23 & $3^{\text {rd }}$ conductive sheet, lower Region of antenna & cs & 52.44 & 4.70 & 1.00 \\
\hline 24 & $4^{\text {th }}$ conductive sheet, lower Region of antenna & cs & 41.00 & 4.70 & 1.00 \\
\hline 25 & $5^{\text {th }}$ conductive sheet, lower Region of antenna & cs & 25.05 & 4.70 & 1.00 \\
\hline 26 & $6^{\text {th }}$ conductive sheet, lower Region of antenna & cs & 14.09 & 4.70 & 1.00 \\
\hline
\end{tabular}


Table 18. Dimensions of regions 1 to 5 in model 4 (Figure 4). Each region has a different shape, and so the number of coordinates needed to describe that shape generally varies.

\begin{tabular}{|c|c|c|c|c|c|c|c|c|c|}
\hline \multicolumn{2}{|c|}{ Region 1} & \multicolumn{2}{|c|}{ Region 2} & \multicolumn{2}{|c|}{ Region 3} & \multicolumn{2}{|c|}{ Region 4} & \multicolumn{2}{|c|}{ Region 5} \\
\hline$\rho(\mathrm{m})$ & $z(\mathrm{~m})$ & $\rho(\mathrm{m})$ & $z(\mathrm{~m})$ & $\rho(\mathrm{m})$ & $z(\mathrm{~m})$ & $\rho(\mathrm{m})$ & $z(\mathrm{~m})$ & $\rho(\mathrm{m})$ & $z(\mathrm{~m})$ \\
\hline 0.07500 & -30.00000 & 0.07500 & -30.00000 & 0.03810 & 0.53060 & 0.03560 & 0.47980 & 0.00000 & 0.21180 \\
\hline 0.07500 & 30.00000 & 0.07500 & 30.00000 & 0.04320 & 0.53060 & 0.03810 & 0.47980 & 0.03810 & 0.21180 \\
\hline 30.00000 & 30.00000 & 0.00000 & 30.00000 & 0.04320 & -0.69370 & 0.03810 & 0.48230 & 0.03810 & 0.47980 \\
\hline 30.00000 & -30.00000 & 0.00000 & 1.14020 & 0.03810 & -0.69370 & 0.03560 & 0.48230 & 0.03560 & 0.47980 \\
\hline & & 0.00480 & 1.14020 & & & & & 0.03560 & 0.48230 \\
\hline & & 0.00480 & 0.73380 & & & & & 0.00000 & 0.48230 \\
\hline & & 0.02220 & 0.73380 & & & & & & \\
\hline & & 0.02860 & 0.56870 & & & & & & \\
\hline & & 0.04320 & 0.54330 & & & & & & \\
\hline & & 0.04320 & -1.39550 & & & & & & \\
\hline & & 0.00000 & -1.47370 & & & & & & \\
\hline & & 0.00000 & -30.00000 & & & & & & \\
\hline
\end{tabular}

Table 19. Dimensions of regions 6 to 10 in model 4 (Figure 4). Each region has a different shape, and so the number of coordinates needed to describe that shape generally varies.

\begin{tabular}{|r|r|r|r|r|r|r|r|r|r|}
\hline \multicolumn{2}{|c|}{ Region 6 } & \multicolumn{2}{c|}{ Region 7 } & \multicolumn{2}{c|}{ Region 8 } & \multicolumn{2}{c|}{ Region 9 } & \multicolumn{2}{c|}{ Region 10 } \\
\hline$\rho(\mathrm{m})$ & $z(\mathrm{~m})$ & $\rho(\mathrm{m})$ & $z(\mathrm{~m})$ & $\rho(\mathrm{m})$ & $z(\mathrm{~m})$ & $\rho(\mathrm{m})$ & $z(\mathrm{~m})$ & $\rho(\mathrm{m})$ & $z(\mathrm{~m})$ \\
\hline 0.00200 & -0.00510 & 0.03810 & 0.08100 & 0.00000 & -0.21180 & 0.03560 & -0.47980 & 0.00000 & -0.21180 \\
\hline 0.00570 & -0.00510 & 0.00570 & 0.00510 & 0.00000 & -0.64490 & 0.03810 & -0.47980 & 0.03810 & -0.21180 \\
\hline 0.00570 & 0.00510 & 0.00570 & -0.00510 & 0.03560 & -0.64490 & 0.03810 & -0.64490 & 0.03810 & -0.08100 \\
\hline 0.00200 & 0.00510 & 0.03810 & -0.08100 & 0.03560 & -0.47980 & 0.03560 & -0.64490 & 0.00570 & -0.00510 \\
\hline & & & & 0.03810 & -0.47980 & & & 0.00200 & -0.00510 \\
\hline & & & & 0.03810 & -0.21180 & & & 0.00200 & 0.00510 \\
\hline & & & & & & & & 0.00570 & 0.00510 \\
\hline & & & & & & & & & \\
\hline
\end{tabular}

Table 20. Dimensions of regions 11 to 15 in model 4 (Figure 4). Each region has a different shape, and so the number of coordinates needed to describe that shape generally varies.

\begin{tabular}{|r|r|r|r|r|r|r|r|r|r|}
\hline \multicolumn{2}{|c|}{ Region 11 } & \multicolumn{2}{c|}{ Region 12 } & \multicolumn{2}{c|}{ Region 13 } & \multicolumn{2}{c|}{ Region 14 } & \multicolumn{2}{c|}{ Region 15 } \\
\hline$\rho(\mathrm{m})$ & $z(\mathrm{~m})$ & $\rho(\mathrm{m})$ & $z(\mathrm{~m})$ & $\rho(\mathrm{m})$ & $z(\mathrm{~m})$ & $\rho(\mathrm{m})$ & $z(\mathrm{~m})$ & $\rho(\mathrm{m})$ & $z(\mathrm{~m})$ \\
\hline 0.00000 & 0.73380 & 0.00000 & 0.56870 & 0.00000 & 0.48230 & 0.00000 & -1.47470 & 0.03802 & 0.21180 \\
\hline 0.00480 & 0.73380 & 0.02860 & 0.56870 & 0.03810 & 0.48230 & 0.04320 & -1.39550 & 0.03802 & 0.25500 \\
\hline 0.00480 & 1.14020 & 0.02220 & 0.73380 & 0.03810 & 0.53060 & 0.04320 & -0.69370 & 0.03810 & 0.25500 \\
\hline 0.00000 & 1.14020 & 0.00000 & 0.73380 & 0.04320 & 0.53060 & 0.03810 & -0.69370 & 0.03810 & 0.21180 \\
\hline & & & & 0.04320 & 0.54330 & 0.03810 & -0.64490 & & \\
\hline & & & & 0.02860 & 0.56870 & 0.00000 & -0.64490 & & \\
\hline
\end{tabular}


Table 21. Dimensions of regions 16 to 30 in model 4 (Figure 4).

\begin{tabular}{|r|r|r|r|r|r|r|r|r|r|}
\hline \multicolumn{2}{|c|}{ Region 16 } & \multicolumn{2}{c|}{ Region 17 } & \multicolumn{2}{c|}{ Region 18 } & \multicolumn{2}{c|}{ Region 19 } & \multicolumn{2}{c|}{ Region 20 } \\
\hline$\rho(\mathrm{m})$ & $z(\mathrm{~m})$ & $\rho(\mathrm{m})$ & $z(\mathrm{~m})$ & $\rho(\mathrm{m})$ & $z(\mathrm{~m})$ & $\rho(\mathrm{m})$ & $z(\mathrm{~m})$ & $\rho(\mathrm{m})$ & $z(\mathrm{~m})$ \\
\hline 0.03802 & 0.25500 & 0.03802 & 0.29820 & 0.03802 & 0.34140 & 0.03802 & 0.38460 & 0.03802 & 0.42770 \\
\hline 0.03802 & 0.29820 & 0.03802 & 0.34140 & 0.03802 & 0.38460 & 0.03802 & 0.42770 & 0.03802 & 0.47980 \\
\hline 0.03810 & 0.29820 & 0.03810 & 0.34140 & 0.03810 & 0.38460 & 0.03810 & 0.42770 & 0.03810 & 0.47980 \\
\hline 0.03810 & 0.25500 & 0.03810 & 0.29820 & 0.03810 & 0.34140 & 0.03810 & 0.38460 & 0.03810 & 0.42770 \\
\hline
\end{tabular}

Table 22. Dimensions of regions 21 to 25 in model 4 (Figure 4).

\begin{tabular}{|r|r|r|r|r|r|r|r|r|r|}
\hline \multicolumn{2}{|c|}{ Region 21 } & \multicolumn{2}{c|}{ Region 22 } & \multicolumn{2}{c|}{ Region 23 } & \multicolumn{2}{c|}{ Region 24 } & \multicolumn{2}{c|}{ Region 25 } \\
\hline$\rho(\mathrm{m})$ & $z(\mathrm{~m})$ & $\rho(\mathrm{m})$ & $z(\mathrm{~m})$ & $\rho(\mathrm{m})$ & $z(\mathrm{~m})$ & $\rho(\mathrm{m})$ & $z(\mathrm{~m})$ & $\rho(\mathrm{m})$ & $z(\mathrm{~m})$ \\
\hline 0.03802 & -0.21180 & 0.03802 & -0.25500 & 0.03802 & -0.29820 & 0.03802 & -0.34140 & 0.03802 & -0.38460 \\
\hline 0.03802 & -0.25500 & 0.03802 & -0.29820 & 0.03802 & -0.34140 & 0.03802 & -0.38460 & 0.03802 & -0.42770 \\
\hline 0.03810 & -0.25500 & 0.03810 & -0.29820 & 0.03810 & -0.34140 & 0.03810 & -0.38460 & 0.03810 & -0.42770 \\
\hline 0.03810 & -0.21180 & 0.03810 & -0.25500 & 0.03810 & -0.29820 & 0.03810 & -0.34140 & 0.03810 & -0.38460 \\
\hline
\end{tabular}

Table 23. Dimensions of region 26 in model 4 (Figure 4).

\begin{tabular}{|r|r|}
\hline \multicolumn{2}{|c|}{ Region 26} \\
\hline$\rho(\mathrm{m})$ & $z(\mathrm{~m})$ \\
\hline 0.03802 & -0.42770 \\
\hline 0.03802 & -0.47980 \\
\hline 0.03810 & -0.47980 \\
\hline 0.03810 & -0.42770 \\
\hline
\end{tabular}

Table 24. Coaxial cable used in model 4 (Figure 4). Type "s" refers to a region with standard or typical electromagnetic properties. Type "pc" refers to a region that is a perfect conductor. For such a region, both the relative dielectric permittivity and the relative magnetic permeability have no significance; consequently, the associated table entries are leaders (---). The dimensions are listed in Table 25.

\begin{tabular}{|r|l|r|r|r|r|}
\hline $\begin{array}{r}\text { Region } \\
\text { Number }\end{array}$ & Description & Type & $\begin{array}{r}\text { Electrical } \\
\text { Conductivity } \\
(\mathrm{S} / \mathrm{m})\end{array}$ & $\begin{array}{r}\text { Relative } \\
\text { Dielectric } \\
\text { Permittivity }\end{array}$ & $\begin{array}{r}\text { Relative } \\
\text { Magnetic } \\
\text { Permeability }\end{array}$ \\
\hline 27 & Inner Conductor & $\mathrm{pc}$ & $\infty$ & --- & --- \\
\hline 28 & Dielectric Sheath & $\mathrm{s}$ & 0.00 & 1.30 & 1.00 \\
\hline 29 & Outer Conductor & $\mathrm{pc}$ & $\infty$ & --- & --- \\
\hline
\end{tabular}

Table 25. Dimensions of the coaxial cable used for model 4 (Figure 4).

\begin{tabular}{|r|r|r|r|r|r|}
\hline \multicolumn{2}{|c|}{ Region 27 } & \multicolumn{2}{c|}{ Region 28 } & \multicolumn{2}{c|}{ Region 29 } \\
\hline$\rho(\mathrm{m})$ & $z(\mathrm{~m})$ & $\rho(\mathrm{m})$ & $z(\mathrm{~m})$ & $\rho(\mathrm{m})$ & $z(\mathrm{~m})$ \\
\hline 0.00000 & -0.02910 & 0.00200 & -0.02910 & 0.00520 & -0.02910 \\
\hline 0.00000 & -0.00510 & 0.00200 & -0.00510 & 0.00520 & -0.00510 \\
\hline 0.00200 & -0.00510 & 0.00520 & -0.00510 & 0.00550 & -0.00510 \\
\hline 0.00200 & -0.02910 & 0.00520 & -0.02910 & 0.00550 & -0.02910 \\
\hline
\end{tabular}

